\title{
Ethic vs. Business, Religion vs. Task
}

\author{
Alena Kusá, Zuzana Danechová, Stanislav Findra \\ Department of Mass - media Communication University of Ss. Cyril and Methodius, Trnava, Slovakia
}

\begin{abstract}
There are issues that are still taboo and displaying them in other than normal situations and stereotypes appears to be controversial. This research study deals with ethics in advertising with a focus on displaying religious symbols in controversial advertising campaigns. Religious motifs are often used with the intent to shock and creators often insensitive cross borders of decency with the intention to provoke, to be different, assume, or sell. The main aim of this research study is to highlight attitudes of advertising agencies toward to clients briefs with ideas or task balanced at the edge of ethics, contracting controversial or inflammatory advertising messages, analyse approaches creators of advertising campaigns and to identify barriers to the acceptance of the sensitivity of these briefs. Research sample includes 7 preselected advertising agencies whose representatives on various job positions through copywriters, account managers, executive staff, PR managers, marketing managers responded to the interview questions relating to the processing of sensitive subjects and religious themes in advertising or PR. This study points out the results of the research from the side of advertising creators who have to adapt to issues such as display religious themes in marketing communications. The research points what is in term of controversial or sensitive issue still acceptable and what they do not want to allow to regulate similar topics. We find if the values and principles of creators can affect the final form of advertising or PR article that gets to the public. Research was conducted via online interviews. Via e-mail we sent out 9 questions about the attitude of creators to ethics, personal values and the use of Christian themes in advertising. The selection criteria were that the worker has to work directly on advertising content according to the client's brief and he or she has to have at least 3 years practice in this area.
\end{abstract}

Index Terms - religious themes and motives; ad creators; values and opinions

\section{Introduction}

In the following text, we highlight the issue of ethics in advertising development, due to the use of religious motives in advertising communicator. Advertisement, as we know it today, it is not about selling and informing, but it often shocks customer by using emotions. Emotions such as humour or fear are common forms of appealing to the target audience in today's practice. But on the other side there are also communicator, that can outrage grater part of the population by its form of processing. Then we can ask ourselves: "What is the moral border of advertising campaign makers in using of religious symbols in ads?"

\section{The Question of Ethics in Marketing Communications}

Wide diapason of studies, research and experience of marketing ethics characterized as a multidimensional scientific discipline (theoretical and practical), which explores the respect for universal ethical principles and the principles of marketing activities [1]. According to the general theory of marketing ethics can be all ethical issues and dilemmas in marketing divided into:

- those that affect marketing as a process. Include the application of unethical marketing strategies,

tactics and procedures (e.g., false or misleading advertising, pricing or sale of dangerous products);

- those that apply to the product in marketing. These questions deal with the ethical appropriateness (suitability) marketing of certain products [2].

Reinforcing the principles of ethics and morality in marketing, particularly in a globalized world requires efforts in several ways: in the regulation, organization, communication and awareness of social responsibility [3]. Message of some campaigns often crosses the boarders and meets different cultures, where the meaning could be different or changed or not accepted [4]. The problem of using religious motives can be confront with reporting actual issues by religious news [5]. Ethic aspects of advertising as one of the variables in the marketing communications mix relate to the three target groups, namely:

- Customers (as recipients of advertising messages, which have been influenced by messages. Then they the execute actions in the form of buying and beliefs about the quality of the advertised product or building brand awareness/product awareness)

- Competitive subjects (subjects that fulfil the same requirements and needs of consumers than the actual submitter of the ad campaign. There is the effort to prevent purposely communicated untrue information about competitor or prevent to informing about less quality of competitor's products)

- The general public (all groups that perceive advertising, have ability to influence the ad or they are influenced by ad, such as clubs, offices, government organizations, media).

People's behaviour, as well as creating advertising campaigns is regulated by certain basic standards - in a form of regulatory standards (laws) or public opinion too [6]. Valentine and Rittenburg describe ethical decisions as a general perception of right and wrong in behaviour. In general terms the ethical decisions as an individual's personal assessment of the extent to which certain behaviour or practice is ethical and unethical [7]. Conscience is one of the fundamental questions of ethics and reflects a person's ability to carry out moral self-control. Conscience is self regulated personal behaviour based on subjective set and understanding of moral obligation. Public opinion is also extremely important part of the advertising campaign because by publication of the advertising campaign in the media, people can create not only a certain opinion, but also opinion about the advertiser and also opinion about the actual creator of the campaign. Fulfilment of the moral demands on the public 
opinion is checked by all the other people. Moral authority depends not on social status or physical background of the person, but it depends on how one understands the sense of moral demands in the community in which person lives [8].

Basic moral principles are formulated as an Ethic Code that reflects general societal norms that apply in the exercise of any profession, as well as advertising creation. By content, we distinguish three types of codes:

1. Aspiration Code - expresses the ideals. These ideals present the goal for practical doing of subject.

2. Educational Code - contains precisely defined guidelines.

3. Regulatory Code - contains detailed discussed ethical requirements [9].

\section{Promotional Messages that Contain Religious Themes}

Advertisement is created to influence consumer's behaviour by using specific items [10]. Items can divide into two basic types that are used for persuasion. Firstly, we describe informational items - information is important for decision making of the target group. Among these information belong price, quality, guarantee, package and so on. Everyday experience suggest that many commercial advertisement are informative to greater or lesser extent. Even though that they may try to manipulate, magazine and television advertisement often contain information as well. [11]. Emotional items involve feeling, not thoughts. Advertisements with emotional content contain many nonverbal elements and stimuli that involve feelings [12].

Church confronts ad creation mainly in two ways: primarily keeps track the overall moral value of advertising campaigns, their form, emotions and how they influence the target audience. As a second aspect, the religious institutions closely monitor the use of religious themes in communicator.

The objective of the advertising campaign is to draw the attention of the target on the product or brand. Creativity of an advertising campaign is not just to have a suitably chosen slogan, or creative story of ad. In today's oversaturated market and the ever growing competition the advertising campaigns are becoming increasingly aggressive, and not only in relation to the competitor but also to the recipient of advertising, since advertising campaigns often work with themes that are perceived by the public as a sensitive approach to such issues and then it requires particular empathy and good application of the theme. These themes are also linked with the question of the use of religion, its symbols, or use religious themes in advertising campaigns. The controversy here is that the ad with a religious undertone might insult not only the Church itself, but also believers in the world. The attitude of Catholic Church in Slovakia on the topic of religious themes in advertising is following: "We see a lot of specific problems in ads which uses and deals with religion or certain question that contain a moral dimension."

It is especially in the case when advertising agencies use religious themes in economic advertisement and his main purpose is to come into circulation certain goods. It's okay if it is done tastefully, with acceptable manner. But this approach tends to be often undignified and insulting, because it does not respect the religion and it only wants to use it." [13].

In connection with mentioned theme (usage of religion and its symbols), we formulate the primary objective of the research and we focus on the opinion of the advertising campaigns creator's to similar topics.

As we wrote, in these days is advertising market oversaturated and it is necessary to avoid the usual clichés. Advertisements contain more hidden meanings. These meanings are in connection with certain well-known story, statement, personal, social problems and so on. Oftentimes we have seen or heard advertising messages disseminated by controversial communicator. Among the sensitive themes that are challenging for every marketer, in our study we focus just on the usage of religious motives, symbols or representatives of Churches in other than normal situations. "Joining ads and religion in most cases causes scandal" [14], as it is written in one of the blogs on the website Media Guru. It is true that the usage of the sensitive topic of religion ends in most cases by controversial debate and that usage can cause banning of the campaign. Examples are presented in an appendix. They represent the visuals campaigns, which main idea is based on using a religion, well-known leaders of Church, or on usage of the Bible stories.

\section{Data Collection and Methodology}

The research sample consisted of representatives from seven agencies working with ad content. Agencies were deliberately chosen in order to cover all segments. We were deliberately focused on agencies that are working with different type of commercial - prints, outdoor ads, audio ads, TV spots, or text ads and agencies working with media content - PR agencies. Research was conducted via online interviews. Via e-mail we sent out 9 questions about the attitude of creators to ethics, personal values and the use of Christian themes in advertising. The selection criteria were that the worker has to work directly on advertising content according to the client's brief and he or she has to have at least 3 years practice in this area. Interview contained open questions, but also questions where respondents were asked to indicate their relationship to individual claims. Total percentage of research sample according to sex, was:

- Male: $43 \%$

- Female: $57 \%$

For each question (except demographic questions) they had an option to add their own comment. Finally, we evaluated the responses and identify attitude of the respondents to the topic of ethics in advertising and the use of religious themes.

\section{Results}

Our research is focused on attitude of the ad creators or redactors/journalist of PR articles in Slovakia. They create visual, audio-visual, or text format of ads based on client's request. Usage of sensitive themes in ads mostly evokes embarrassed reactions and then ad recipients do not accept 
used ad 's form. So, we try to find out what are the critical factors in creating ad's content that work with sensitive issues.

Process of ad creation is complicated and represent a systematic team work. It consist of many activities - the setting of the primary idea, the process of brainstorming, processing of proposals, presentations, sometimes repeated revision and final approval of the proposals by both the client, but also often by superior. Analysis of the first results showed that representatives of agencies consider client's assignment the most crucial $(43 \%)$ during ad process creation. Second crucial factor is satisfaction of the boss.

Based on the results, own values, opinions and persuasion are not important factors for final result in ad process creation. On the other side, account managers, marketing consultants, PR managers, graphic designers, copywriters etc., from a sociological point of view, each of them represents a personality with own opinions, views and feelings. Therefore, we were interested in it, which topics and themes in advertising they evaluated as provocative or controversial. Answers of representatives were mostly identical. Respondents identified several controversial themes:

- racial discrimination, discrimination against minorities, prejudices

- excessive nudity, sex

- sexism, positioning of the women

- religious themes

- theme wealth, luxury and exalted

- abortion

Communication between an advertising agency and the client is very important for a final outcome. This relationship, attitude, access, openness of client to agency' employees attitudes, or an effort to advice frequently form of ad, which gets to the public. In the research, we also focused on find out the attitude to usage of controversial topics in advertising.

$45 \%$ of respondents answered, that they tried to use a controversial themes very sensitive. $18 \%$ of respondents answered, that the most important are client requirements (if client wants or do not want to use controversial theme in ad) they accept client's decision, $18 \%$ of respondents also answered, that for better result, they try to suggest even more controversial variant. Some of respondents answered, that an important is final satisfaction too. Sometimes they try to suggest another variant of motives. While they use theme, which is in public view controversial (but they consider that theme as an acceptable), finally they use that theme in advertisement.

In the research was also analysed an importance of ethics, because a creation of ad campaigns is regulated by norms (laws, public opinion ...). We asked respondents: Is for you important to create an ad according to ethic norms?

As we found out, $63 \%$ percent of ad creators answered that they accept Ethic Code importance as a regulation norm for them. Up to $25 \%$ are not afraid to risk a penalty if the ad has fulfilled the original intention. Some representatives of agencies added that depending on the target audience and the specific assignment.

In the following phase of research, we analysed the usage of religious motives, for example figures of saints, Sign of the Cross, Bible stories, etc. and we ask if usage of religious motives is in accordance with personal beliefs of respondents.

According to the responses $57 \%$ ad creators would use religious motives in ad. Since the aim of advertising is to sell, often themselves the creators tested how far they can go and what the public can accept. It is true that the admissibility limits are shifted in accordance with the lifestyle. We are constantly faced with shocking ads, slogans, texts, articles that can provoke and cause embarrassed reaction mixture. If you want the agency to experiment and try out what the public can accept, it may happen that agencies sometimes "overshoot". So, we focused on how the ad creators react after their advertising causes negative emotions. Often the form of inappropriate ad can "damage" not only the agency name, but also the name of ad creator, or a team. Is it crucial for the creators?

Respondents added that depending on the own satisfaction with the result. An important is result, result for which the creators know to defend it. But what if the client requires creating the campaign, advertisement, or article, with which the authors do not identify themselves? Already at the beginning of our study, we wrote that conscience is a fundamental question of ethics and reflects a person's ability to carry out moral self-control. Conscience represents selfregulating personal behaviour based on subjective set and understood moral obligation. According to the results of the research:

- $38 \%$ of respondents said that if the client is satisfied, creator's conscience is not important

- $13 \%$ answered "what brings profit, it satisfies me/my conscience

- $25 \%$ said they would never created anything that would contrary to their conscience

- $24 \%$ concreted their answer and added that their position cannot afford to choose whether or not to realize the assignment. There are an important assignments and advertising creators try to satisfied a client. Similarly, they added that they always try to consider the different views on the assignment and offer the best possible solution.

\section{Conclusion}

We concluded the research by using additional questions in which respondents were asked to express the degree of agreement or disagreement. We found out the final attitude on values. 
Table 1: Attitude of respondents to selected values

\begin{tabular}{|c|c|c|c|c|}
\hline Value & Question & Agree & It depends on specific circumstances & Disagree \\
\hline Conscience & Conscience and own values are not important & $29 \%$ & $28 \%$ & $43 \%$ \\
\hline Money & In the centre of attention is money & $14 \%$ & $43 \%$ & $43 \%$ \\
\hline Courage to risk & Risk $=$ profit, so why couldn't I provoke? & $29 \%$ & $57 \%$ & $14 \%$ \\
\hline
\end{tabular}

As stated in its publication of Vít Baloušek Business relationships and morality, it is a big topic. The task and challenge is to precisely link morality with the world of business and marketing. Honestly, who today cares about ethics and morality? The company is always built on shared values, they are a source of orientation in our lives when deciding what is good and what is bad. Advertising tells us what to do and it is up to us how we choose. We are free beings. [15] It is clear that each individual has its own principles and values. For people in the agencies creating ads or articles is their job. Client pays for the results what could make him satisfied and bring the profit, sell or build the brand. And it is not always easy, despite the opposition of the award firmly say no. Complete attitude can be summarized by answers to the last question. The last question was formulated following: Would you refuse a client if his requirement to creating an ad was in conflict with your persuasion? Results were: $71 \%$ of respondents said they are not willing to lose a client, and only $29 \%$ would be willing to refuse a client.

This text is a partial result of Project VEGA no. $1 / 2083 / 15$ "Aspects of marketing communication in customer's value process creation at B2C market in context with maximization of market share in retail gravity"

\section{References}

[1] P. Kotler, G. Armstrong, "Principles of marketing, “ Essex, England: Pearson Education, 2010, pp.736.
[2] O. C. Ferell, M. Hartline, "Marketing strategy,“ Brand New: Cengage Learning, 2010, pp. 743.

[3] S. R. Valentine, T.L. Rittenburg, "Ethical evaluation in global situations," Journal of Business Ethics, vol.9, no. 3, pp. 50 - 54, 2004.

[4] M. Hrubec, "Predictions of an intercultural communication,“ Communication Today vol. 5, no.2, pp. 33, 2014.

[5] T. Rončáková, "Political affairs in the catholic news. Attitude and impulses of active readers, "Communication Today, vol. 5, no.2, pp. 81, 2014.

[6] H. Pravdová, J. Radošinská, "Media Culture in the context of transformation of contemporary spiritual values and spirituality," European Journal of Science and Theology, “ vol. 9, no.6, pp. $169-178,2013$.

[7] D. Hrehová, "Analýza štruktúry publikovania výstupov z oblasti vyučovania marketingovej etiky," Communication today, vol. 3, no.2, pp. 74-93, 2012.

[8] M. Agafonová, "Etika,“ Košice: Technická Univerzita v Košiciach, 2006, pp. 72.

[9] A. Remišová, "Etika médií,“ Bratislava: Arkus, 2010, pp. 89.

[10] V. Hrabačková, M. Sabo, "How Many Offers Does Slovak Consumer Need?," Communication Today, vol. 3, no. 1, pp. 99, 2012.

[11] M.J. Philips, "Ethics and manipulation in advertising," Westport: Quorum books, 1997, pp. 211.

[12] P. D. Pelsmacker, M. Guens, J. V. D. Bergh, "Marketingová komunikace," Praha: Grada Publishing, 2003, pp. 600.

[13] Pontifical Council for Social Communications: http://www.kbs.sk/obsah/sekcia/h/dokumenty-avyhlasenia/p/dokumenty-vatikanskych-uradov/c/etika-reklamy

[14] Controversial Ad : Ref. Religious http://www.mediaguru.cz/2012/05/kontroverzni-reklamy-znnabozenske/\#.UfTPGNK-2So

[15] V. Baloušek, "Žijte a myslete kreativne," Brno: Computer Press a.s., 2011, pp. 206. 